\title{
The Effect of Thematic Progression Pattern Toward Students' Writing Expository Paragraph
}

\author{
Fitri Nurdianingsih ${ }^{1}$, Yuniarta Ita Purnama ${ }^{1}$ \\ ${ }^{1}$ English Education Department of IKIP PGRI Bojonegoro. Jl. Panglima Polim No. 46. \\ Bojonegoro. East Java.
}

\begin{abstract}
Writing is a complex skill to be mastered by the university students. This skill involves not only cognitive aspect but also affective aspect such as emotions, apprehension, and motivation. The objective of this research was to find out whether there is a significant different between the students' writing skill after being taught using Thematic Progression Pattern and Direct Instruction. The research design used is quasi experimental research. There were two classes in this research, experimental class which was taught using thematic progression pattern and control class which was taught using direct instruction. The population of this research was all of the second semester students at English Department of IKIP PGRI Bojonegoro in academic year 2016/2017. The sampling technique was cluster random sampling. Technique of collecting data used was writing skill test. To analyze the data, $t$ - test formula was used. Through this technique, the students can develop their ideas into a good writing.
\end{abstract}

Keyword: Thematic Progression Pattern; writing; and expository paragraph

\section{INTRODUCTION}

English has become the essential language since it is used as not only one of an international and global languages, but also in most countries in the world English becomes the second language. In Indonesia, English is learned as a foreign language. English is taught since in an elementary school until university level, even it is already taught in a level of kindergarten. That shows how essential the language the language is in our country as a developed country.

In order to be successful, students need to master the four language skills such as reading, writing, listening, and speaking. According to Heaton (1975: 3) [1] the four major skills in communicating through language are often broadly defined as listening, speaking, reading, and writing. Each of the language skill has relationship to others and should be taught in integrative way. Meyers (2005:2) [2] states that writing is an action, a process of discovering and organizing our ideas, putting them on the paper and reshaping also revising them. 
Many centuries ago, writing was a skill that was the exclusive domain of scribes and scholars in educational and religious. Today, the abiliy of writing has become an indispensable skill in global literate community (Brown, 2004: 218) [3]. Writing is transforming thought into language; it means that the writer needs to think about the content of writing first and then contruct the ideas using appropriate language.

Regardless of their major, university students are required to try different types of writing, such as term papers or exam answers, throughout their studies. Moreover, the students must write a research paper as their final project at the end of their study in university. The students will be considered "pass or fail" from their study depending on this research paper (Ghufron, 2015) [4]. One of the text type that students should master in order to be able to write a research paper is expository essay.

In fact, there are so many students got some problems in writing skill, especially expository essay. The problems sometimes arouse from the lack of vocabularies, motivation, and grammar. The difficulties in vocabulary such as on how to use the vocabulary, and how to arrange them into a good sentences and paragraph. So that it is necessary for the researcher to conduct the research to find what method that should be use to solve the students' problem especially in writing skill.

Writing is generally recognized as a difficult task for language learners, especially foreign language learners. Maintaing the cohesion in their writing is the main problem faced by the students. In fact, cohesion is needed when writing something. The writer have to keep cohesion in their writing. Thematic progression pattern can be used as one of the learning method in order to keep the cohesion of their writing.

Thematic progression refers to the way the theme of a clause may pick up or repeat, a meaning from a preceding theme and rheme. Because readers need to reassured that they are following the development of the text, many text are signposted by placing elements from the rheme of one clause into the theme of the text, or by repeating meanings from the theme of one clause in the theme of subsequent clauses.

The objectives of this research are to find out whether there is a significant different or not between the students' writing skill after being taught using Thematic Progression Pattern and direct instruction to the second semester students at English Education Department of IKIP PGRI Bojonegoro .

The hypothesis of this research can be formulated as follow: there is a significant different between the students' writing skill after being taught using Thematic Progression Pattern and direct instruction to the second semester students at English Education Department of IKIP PGRI Bojonegoro. 


\section{RESEARCH METHOD}

The design used in this research is pretest-posttest control group design. This research was conducted in two classes, one class as the experimental class and one as the control class. Thematic Progression Pattern was used to teach writing in experimental class. Then, Direct Instruction was used to teach in control class.

The research was carried out at the second semester at English Education Department of IKIP PGRI Bojonegoro. The number of the students in each class is 30 students, so there were 60 students as sample. The researcher used cluster random sampling.

In this research, the researcher used test as an instruments of collecting data. There was writing skill test. Writing skill test was used to measure the students' writing skill by using scoring rubrics of writing. The indicators of writing skill are organisation, content, grammar, mechanics, style and quality.

The technique of analyzing data were descriptive and inferential analysis. Descriptive analysis was used to know the mean, median, mode, and standard deviation of the scores of students' writing skill test from both groups. Inferential analysis was used t-test formula.

\section{RESEARCH FINDING}

\section{Pre-test and Post-test Analysis}

After delivering pre-test, the researcher calculated the mean score for both the experimental group. The mean score for experimental group was 77.23, while the mean score for control group was 78.00. Here is the comparison chart of the pre-test between the experimental and control group based on the writing components.

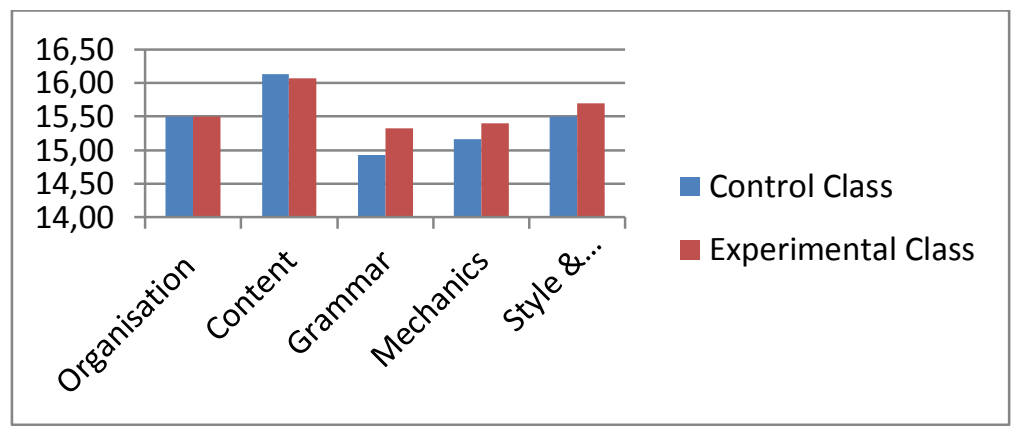

Figure 1. The Mean Score in Pre-test of Experimental and Control Group 
From the Figure 1, we can see that the results of the mean score for both group were almost the same. It can be said that the writing skill of both two groups were at the same level.

In the pre test, the students experienced difficulties. The first thing that came up to the researcher's mind was the way the students organized their ideas. There were some students still used Indonesian language to make their draft, then they translated it in English. Most of their writing had errors in grammar, their verbs and spelling.

The researcher also conducted and calculated the mean score from the posttest. The mean score for the experimental group was 88,13 , while the mean score for the control group was 83.13. here is the comparison chart of the post-test between the experimental and control group based on the writing components.

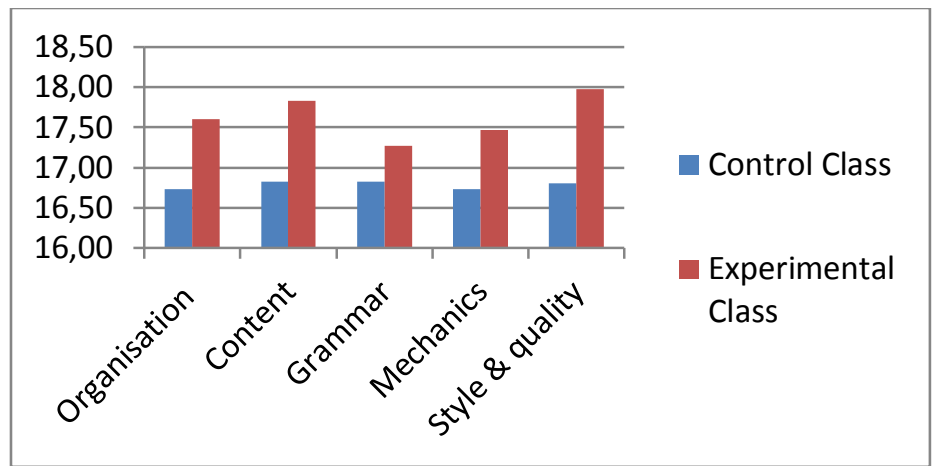

Figure 2. The Mean Score in Post-test of Experimental and Control Group

From the result of post-test, it can be said that the experimental and control groups' writing skill improved. It can be seen from the mean scores of the students for the both groups. However, the experimental and the control group have different level of achievement in writing skill.

In the post test, the both two groups had improved their writing skill. Their content had related to the organisation. They were able to manage their ideas into a good writing. Beside that, the students could more focus on their topic and start to write down their words easily.

The last step was the researcher calculated $t$ value. Then, the researcher comparing th calculated $\mathrm{t}$ value with $\mathrm{t}$ table value. From the calculation, the $\mathrm{t}$ table for df 58 with the level of significant $5 \%$ is 2.02 . The calculation $t$ value was 4.64. It means that the calculation $t$ value is higher than $t$ table, so the different of means between the experimental and control group is significant. It can be condluded that the use of Thematic Progression Pattern can be an appropriate technique to applied in writing an expository paragraph. 


\section{DISCUSSION}

Theme and thematic progression (T/TP) is a major aspect of "how speakers construct their messages in a way which makes them fit smoothly into the unfolding language event" (Thompson, 2014: 117) [8]. The Theme is the starting point of a message, "that which the clause is about" (Halliday, 2014: 89) [9]. It is followed by the Rheme, which is "part of the assembly of the new information that the text offers" (Cummings, 2003: 133) [10]. What comes first (i.e., in Theme position) in an English clause is vital for how readers view the text as message because they are culturally primed to have certain expectations about Theme and Rheme (Hoey, 2005) [11]. As the text unfolds, the Themes connect to the Themes and Rhemes of preceding clauses in various ways, picking up or repeating the important concepts and developing them further. These connections form patterns of thematic progression (Daneš, 1974).

From the findings of this research, it can be seen that thematic progression pattern was effectively improve students writing skill in terms of organization. The findings were in line with some researches which deal with the usefulness of T/TP as a tool to characterize EFL/ESL writing as successful or less successful in terms of coherence (Bloor \& Bloor, 1992; Christie \& Dreyfus, 2007; Rørvik, 2012; Schleppegrell, 2004, 2009; Vande Kopple, 1991; Wang, 2007; Wei, 2013a, 2013b; Wei, 2014) [11-21]. However, as Hawe and Thomas (2012) pointed out, while native speakers of English may have acquired how to use T/TP to produce coherent discourse when they grow up learning the language, EFL/ESL students are yet to learn what kind of information to place in the Theme position and how to continually pick up the information which is already in the text and repeat it in some way so that the reader is always aware of what the key concepts are and how the key concepts are being developed [22,23].

TPP activity gives students the opportunity to apply the knowledge of T/TP they acquired in previous sessions and practice identifying T/TP patterns in short texts before they attempted to analyze longer texts. The identification of the thematic structure of the text is accompanied by a discussion on how the information flows to make the text coherent which could help students understand how the meaning and purpose of a text unfolded when these elements were effectively arranged [13].The students are required at this stage to write a conclusion to the composition on "Three advantages of Internet". Session 10 presents to the students the Themes that did not form progression, i.e., back Themes, new Themes and contextual Themes. Wang (2007: 167) found that when students did not properly control how information moved from Theme to Rheme, "there is no clear signpost directing the reader, who therefore cannot easily follow the progression of an idea or argument". It is not enough just analyzing how coherence is created through the progression of Themes and Rhemes in a successful text to provide a model for students to improve the coherence of their own writing. The students also need to know the bad examples of information 
organization. They are asked to revise the whole piece of writing at the end of activity. This session also concludes the training by going through the key concepts briefly and the students' peer reviewing each other's writing for T/TP and then analyzing their own texts.

\section{CONCLUSION}

Based on the the findings, it can be concluded that there is a significant different between the students who are taught using Thematic Progression Pattern and who are taught using Direct Instruction. All of the activities in this instructional package were designed to build students' knowledge of coherence and TTP in order to give students more grammatical resources to improve the coherence of their writing. Furthermore, these activities help students become aware of how information and ideas should flow in a text so that it could be easily understood by the reader. In addition, students would apprehend which TTP patterns are valued in English writing. Finally, these activities provide students with the opportunities to apply this knowledge to improve their own writing. Coherence is both text-based and reader-based, which could be promoted by appropriate thematic choices and TP patterns, therefore, applying this instructional package in English writing teaching and investigate the effect of instruction on English learners' use of TTP would be a good direction in future research in this area.

\section{REFERENCES}

[1] Heaton, J. B. 1975. How to Teach Writing. New York: Longman

[2] Meyers, A. 2005. Gateways to Academic Writing: Effective Sentences, Paragraph, and Essays. New York: Pearson Education.

[3] Brown, H. Douglas. 2004. Language Assessment: Principles and Classroom Practices. New York: Longman.

[4] Ghufron, M. A. 2015. Enhancing Students' Academic Writing Skill by Using Research Paper Writing Instructional Materials. Lensa: Kajian Kebahasaan, Kesusastraan, dan Budaya, $5(2)$.

[5] Alnufaie, M. \& Grenfell, M. 2013. EFL Writing Apprehension: The Macro or the Micro? Journal of Arts and Humanities (2): 79-89.

[6] Daly, J. A. Writing Apprehension in the classroom: Teacher role expectancies of the apprehensive writer. Research in the Teaching of English. 13 (1): 37-44

[10] Cummings, M. 2003. The role of Theme and Rheme in contrasting methods of organization of texts. In C. Butler (Ed.), Dynamics of language use: Functional and contrastive perspectives (pp. 129-154). Amsterdam/Philadelphia: John Benjamins.

[9] Halliday, M.A.K. 2014. Halliday's introduction to functional grammar (4th ed.). Revised by C.M.I.M. Matthiessen. New York: Routledge.

[8] Thompson, G. 2014. Introducing functional grammar (3rd ed.). Abingdon: Routledge.

[11]Hoey, M. 2005. Lexical priming: A new theory of words and language. New York: Routledge. 
[12]Bloor, M., \& Bloor, T. 1992. Given and new information in the thematic organization of text: An application to the teaching of academic writing. Occasional Papers in Systemic Linguistics, 6(1), 33-43.

[13]Christie, F., \& Dreyfus, S. 2007. Letting the secret out: Successful writing in secondary English. Australian Journal of Language and Literacy, 30(3), 235-247.

[14]Rørvik, S. 2012. Thematic progression in learner language. In S. Hoffmann, P. Rayson \& G. Leech (Eds.), English corpus linguistics: Looking back, moving forward (pp. 165-177). Amsterdam: Rodopi.

[15]Schleppegrell, M. J. 2004. The language of schooling: A functional linguistics perspective. Mahwah: Lawrence Erlbaum.

[16]Schleppegrell, M. J. 2009. Grammar for generation 1.5.: A focus on meaning. In M. Roberage, M. Siegal \& L. Harklau (Eds.), Generation 1.5 in college composition: Teaching academic writing to U.S.-educated learners of ESL (pp. 221-234). New York: Routledge.

[17]Vande Kopple, W. J. 1991. Themes, thematic progressions, and some implications for understanding discourse. Written Communication, 8(3), 311-347.

[18]Wang, L. 2007. Theme and rheme in the thematic organization of text: Implications for teaching academic writing. Asian EFL Journal, 9(1), 164-176.

[19]Wei, J. 2013a. Corpus-based research on the development of thematic choices in Chinese learners' English speech. Journal of Education and Practice, 4(16), 38-45.

[20]Wei, J. 2013b. Corpus-based research on topical thematic choices in Chinese and Swedish English learners' English writing. Theory and Practice in Language Studies, 3(12), 22022208.

[21]Wei, J. 2014. Theme and thematic progression in learner English: A literature review. Colombian Applied Linguistics Journal, 16(1), 67-80.

[22]Hawes, T.P., \& Thomas, S. 2012. Theme choice in EAP and media language. Journal of English for Academic Purposes, 11, 175-183.

[23]Hyland, K. 2004. Genre and second language writing. Ann Arbor: University of Michigan Press. 